\title{
Preliminary Studies on the Humoral Immune Response of Mulberry Silkworm, Bombyx mori Larvae Fed on Different Mulberry Varieties
}

\author{
Kariman M. Mahmoud \\ Plant Protection Department, Faculty of Agriculture Suez Canal University, Ismailia, Egypt
}

Received: $4 / 12 / 2020$

\begin{abstract}
Diseases infecting silkworms cause 30-40\% cocoon crop loss. The silkworm, Bombyx mori L. defense against pathogens is provided by open circulatory system through humoral and cellular response. Three mulberry varieties, Morus alba var. Rosa, M. alba var. Morittiana and M. alba var. Laevigata, were used to study the effect of host plant and bacterial contagious infection on the humoral immune of $B$. mori larvae. The specific activity of related enzymes in haemolymph of fifth instar larvae was estimated. Results indicated that mulberry varieties and bacterial contagious infection had significant effects on enzymes activity values in larval haemolymph. Moreover, $M$. alba var. laevigata was superior in the humoral immune response.
\end{abstract}

Keywords: Bombyx mori L., Antimicrobial proteins, humoral immunity, Mulberry varieties

\section{INTRODUCTION}

One of the yield limiting factors in silkworm crop are diseases. Insects have powerful defense mechanisms to fight infections by possessing an efficient innate immune system. The silkworms, B. mori, defense against pathogens divided to the primary defense which prevent the infection by body structural barriers and the secondary defense that provided by insects open circulatory system, haemolymph, through cellular and humoral response (Lemaitre and Hoffmann, 2007; Montano et al., 2011).

Changes in the haemolymph biochemical composition reflect the biochemical modification in the insect body in response to infections. Thus antimicrobial proteins play major roles in humoral immunity, whereas melanization is involved in both humoral and cellular immune responses (Rosales, 2017; Yang et al., 2018).

Variation in immune defenses caused by nutritional contents in host plants were studied in different insects such as the cabbage looper, Trichoplusia ni (Shikano et al., 2010), Spodoptera litura (Vengateswari et al., 2020), the European grape berry moth, Eupoecilia ambiguella (Vogelweith et al, 2015) and Grasshopper Schistocerca gregaria (Emad et al., 2016).

From many years ago till now, many studies focused on mulberry varieties and their effects on economic traits and growth of silkworms, on the other hand, many efforts had been done by genetic breeding to find out a diseases resistance hybrids of $B$. mori (Alipanah et al., 2020; Hema et al., 2011; Hou et al., 2013; Kumar and Naik, 2011). But no investigations were done on the effect of mulberry varieties on immune response or disease tolerance. Thus current study aims to study the direct effect of the sole host plant, mulberry varieties, on the larvae immune responses and bacterial contagious infection tolerance.

\section{MATERIALS AND METHODS}

Silkworm, Bombyx mori larvae rearing and treatment:

Silkworm eggs, the four-way hybrid $(\mathrm{KK} \times$ Hesa 1) $\times($ Vesletz $2 \times$ Gergana 2), imported from

*Corresponding author e-mail: karimanmm@gmail.com
Sericulture and Agriculture Experiment Station, Vratza, Bulgaria were used. After hatching, larval instars fed on clean washed mulberry leaves four times daily which collected from un-infested plants at the Suez Canal University Farm, Ismailia, Egypt. Removal of fecal matter and bed cleaning was done consistently. The silkworm rearing was conducted in the laboratory following the method described by Mahmoud (2017).

Mulberry leaves of Morus alba var. Morittiana, $M$. $a l b a$ var. Rosa and M. aba var. Laevigata (grafted on $M$. alba var. Morittiana origin) were introduced to feed larvae from hatching till cocooning, All experimental treatments were triple replicated, each replicate contains 100 larvae.

Depending on bacterial contagious symptoms, Joshi (2013) and previous obtained results of identification of two pathogenic bacterial strains, Bacillus megaterium and Bacillus circulans, isolated from silkworm larvae, Abou El-Ela (2016), ten naturally bacterial infected and non-infected larvae from each replicate were randomly picked then punctured their proabdominal leg to collect haemolymph samples separately in glass tubes as pooling samples, deep freezed at $-20^{\circ} \mathrm{C}$ as stock and used whenever required.

\section{Enzyme haemolymph preparation and analysis:}

The haemolymph was collected from the larvae of B. mori in a chilled tube coated with ice then centrifuged for $10 \mathrm{~min}$ at 2500 r.p.m. to remove the blood cells.

\section{Phenoloxidase}

(PO) The dopa chrome formation was determined spectrophometrically at O.D. $490 \mathrm{~nm}, 30 \mathrm{~min}$ later.

One enzyme activity unit was defined as the amount of enzyme which causes a change of 0.001 OD490 per minute. Specific activity was calculated in terms of units/mg total plasma protein determined by Bradford assay. Phenoloxidase activity was determined according to a modification of Ishaaya (I971).

\section{The lysozymes:}

The lysozyme activity was determined using the turbidity method according to De Azambuja et al. 
(1991) with slight modifications. One unit of enzyme activity is defined as the amount of enzyme that decrease the absorbance reading at rate of 0.001 absorbance units per min per $u l$ sample in one $\mathrm{ml}$ of the reaction described.

\section{Peroxidase:}

Peroxidase (POD) specific activity was determined according to Vetter et al. (I958) and expressed as (units $\mathrm{x} 10^{3} / \mathrm{min} / \mathrm{mg}$ protein One unit was defined as an increase in absorbance of 0.001 per min and the enzyme activity was expressed as units of enzyme/mg protein

\section{Nonspecific esterases:}

Alpha esterases ( $\alpha$-esterases) and beta esterases $(\beta$ esterases) were estimated according to Van Asperen (I962) using $\alpha$-naphthyl acetate or $\beta$-naphthyl acetate as substrates, respectively.

\section{Glutathione S-transferase (GST)}

Glutathione S-transferase (GST) catalyzes the conjugation of reduced glutathione (GSH) The conjugate, S-(2,4-dinitro-phenyl)-L-glutathione could be detected as described by the method of Habig et al. (1974). One unit of enzyme activity is defined as the amount of enzyme that decrease the absorbance reading at rate of 0.001 absorbance units per min per $u l$ sample in one $\mathrm{ml}$ of the reaction described.

\section{Statistical analysis}

Data were analyzed using SPSS program version 22.0 (SPSS 2008), which used independent samples ttest to compare means of enzymes units in infected and non-infected larvae and one way ANOVA. Statistical significance was assigned as $(\mathrm{p} \leq 0.05)$.

\section{RESULTS}

Effect of mulberry varieties on enzymes activity in haemolymph of Bombyx mori larvae:

Data in Table (1) and Figure (1) show the enzymes specific activity in larvae haemolymph fed on the tested mulberry varieties.

\section{Phenoloxidases (PO) specific activity:}

PO specific activity were $307.67,384.00$ and 340.0 (units $/ \mathrm{mg}$ protein) in non-infected larvae fed on $M$. alba var. Rosa, M. alba var. Morittiana and M. alba var. Laevigata leaves, respectively. On the other hand, (PO) sp. activity was 208.67, 346.67 and 444.67 (units/mg protein) in infected larvae fed on $M$. alba var. Rosa, $M$. alba var. Morittiana and M. alba var. Laevigata, respectively.

\section{Lysozymes specific activity:}

Data indicated that there were no significant differences between lysosomes sp. activity values in non-infected larvae fed on all tested mulberry varieties, they were 29.03, 27.57 and 28.87 (Unit /mg protein) in larvae fed on $M$. alba var. Rosa, M. alba var. Morittiana and $M$. alba var. Laevigata leaves, respectively. While lysosomes values in infected larvae fed on M. alba var. Rosa, M. alba var. Morittiana and
M. alba var. Laevigata, were 20.80, 27.33 and 33.700 (units/mg protein), respectively.

\section{Specific activity of Peroxidases (POD):}

Peroxidases activity had similar trend in noninfected and infected larvae which recorded the significant highest and lower values in larvae fed on $M$. alba var. Laevigata and $M$. alba var. Rosa leaves, respectively. In non-infected larvae (POD) sp. activity registered 43.33, 65.67 and 78.67 while sp. activity registered 42.00, 62.00 and 67.00 (units/mg protein) in haemolymph of infected larvae fed on $M$. alba var. Rosa, M. alba var. Morittiana and M. alba var. Laevigata leaves, respectively.

\section{Nonspecific esterases:}

Nonspecific esterases sp. activity values registered different trend in larvae fed on the different mulberry varieties, which were $2930.00,3204.00$ and 2297.00 (unit/mg protein) in non-infected while sp. activity were 3149.33, 4164.33 and 7141.00 (units/mg protein) in infected larvae fed on $M$. alba var. Rosa, M. alba var. Morittiana and $M$. alba var. Laevigata leaves, respectively. A significant increasing in esterases values were estimated in haemolymph of larvae fed on all mulberry verities except in haemolymph of larvae fed on M. alba var. Rosa

\section{Glutathione S-transferase (GST):}

GST sp. activity were $333.67,389.00$ and 462.67 (units /mg protein) and 500.33, 494.33 and 683.67 (units $/ \mathrm{mg}$ protein) in non-infected and infected larvae fed on M. alba var. Rosa, M. alba var. Morittiana and M. alba var. Laevigata leaves, respectively.

Effect of bacterial contagious infection on enzymes activity in haemolymph of Bombyx mori larvae fed on different mulberry varieties:

Data in Table (2) and Figure (1) compare (PO) sp activity in infected and non-infected larvae, (PO) activity was low in infected larvae fed on $M$. alba var. Morittiana and $M$. alba var. Rosa leaves, on the opposite, PO activity was significantly higher in infected than in non-infected larvae fed on $M$. alba var. Laevigata leaves.

The effect of bacterial contagious infection on lysosomes values show that infected larvae have lower enzyme sp. activity value than in non-infected larvae fed on $M$. alba var. Rosa, while no changes found in larvae fed on $M$. alba var. Morittiana leaves. On contrary, lysosomes activity was higher in infected larvae than in non-infected larvae fed on $M$. alba var. Laevigata leaves. Bacterial contagious infection has a reduction effect in peroxidases activity in larvae fed on all the three mulberry verities. This reduction was significant only in larvae fed on $M$. alba var. Laevigata leaves.

There were no significant differences in GST levels between non-infected and infected larvae fed on all mulberry varieties, while GST values were the highest in haemolymph of infected larvae fed on $M$. alba var. Laevigata leaves. 
Table (1): Mean of enzymes sp. activities of non-infected and infected Bombyx mori larvae fed on different varieties of mulberry leaves.

\begin{tabular}{|c|c|c|c|c|c|c|c|c|c|c|}
\hline \multirow{3}{*}{ Mulberry varieties } & \multicolumn{10}{|c|}{ Mean of enzymes specific activity } \\
\hline & \multicolumn{2}{|c|}{ Phenoloxidase } & \multicolumn{2}{|c|}{ Lysosomes } & \multicolumn{2}{|c|}{ Peroxidase } & \multicolumn{2}{|c|}{ Nonspecific Esterases } & \multicolumn{2}{|c|}{ GST } \\
\hline & $\begin{array}{c}\text { Non- } \\
\text { infected }\end{array}$ & Infected & $\begin{array}{c}\text { Non- } \\
\text { infected }\end{array}$ & Infected & $\begin{array}{c}\text { Non- } \\
\text { infected }\end{array}$ & Infected & Non-infected & Infected & Non-infected & Infected \\
\hline Morusalba var. Rosa & $\begin{array}{c}307.67 \pm \\
15.70 \\
\end{array}$ & $\begin{array}{c}208.67 \pm \\
21.60 \\
\end{array}$ & $\begin{array}{c}29.03 \pm \\
1.12 \\
\end{array}$ & $\begin{array}{c}20.80 \pm \\
1.18 \\
\end{array}$ & $\begin{array}{c}43.33 \pm \\
5.86\end{array}$ & $\begin{array}{c}42.00 \pm \\
4.36\end{array}$ & $\begin{array}{c}2930.00 \pm \\
238.14\end{array}$ & $\begin{array}{c}3149.33 \pm \\
523.61\end{array}$ & $\begin{array}{c}333.67 \pm \\
57.83\end{array}$ & $\begin{array}{c}500.33 \pm \\
88.10 \\
\end{array}$ \\
\hline $\begin{array}{l}\text { Morus alba var. } \\
\text { Morittiana }\end{array}$ & $\begin{array}{l}384.00 \pm \\
23.52\end{array}$ & $\begin{array}{l}346.67 \pm \\
25.58\end{array}$ & $\begin{array}{c}27.57 \pm \\
2.00\end{array}$ & $\begin{array}{c}27.33 \pm \\
1060\end{array}$ & $\begin{array}{c}65.67 \pm \\
7.77\end{array}$ & $\begin{array}{c}62.00 \pm \\
7.00\end{array}$ & $\begin{array}{l}3204.00 \pm \\
207.59\end{array}$ & $\begin{array}{c}4164.33 \pm \\
514.71\end{array}$ & $\begin{array}{c}389.00 \pm \\
60.67\end{array}$ & $\begin{array}{c}494.33 \pm \\
26.86\end{array}$ \\
\hline $\begin{array}{l}\text { Morus alba var. } \\
\text { Laevigata }\end{array}$ & $\begin{array}{c}340.0 \pm \\
5.51\end{array}$ & $\begin{array}{c}444.67 \pm \\
47.25\end{array}$ & $\begin{array}{l}28.87 \pm \\
2.76\end{array}$ & $\begin{array}{c}33.70 \pm \\
4.50\end{array}$ & $\begin{array}{l}78.67 \pm \\
26.29\end{array}$ & $\begin{array}{c}67.00 \pm \\
4.58\end{array}$ & $\begin{array}{c}2297.00 \pm \\
316.07\end{array}$ & $\begin{array}{l}7141.00 \pm \\
281.26\end{array}$ & $\begin{array}{l}462.67 \pm \\
39.37\end{array}$ & $\begin{array}{c}683.67 \pm \\
51.19\end{array}$ \\
\hline Sig.** & .016 & 0.00 & 0.657 & 0.004 & 0.002 & 0.003 & 0.013 & 0.00 & 0.067 & 0.014 \\
\hline \multicolumn{11}{|c|}{$\begin{array}{l}\text { Mean } \pm \text { standard deviation } \\
\text { ns Means no significant differences between treatments } \\
* * \text { Means significance between the same column }\end{array}$} \\
\hline \multirow{2}{*}{ Mulberry varieties } & & \multicolumn{9}{|c|}{ Mean of enzymes specific activity } \\
\hline & & \multicolumn{2}{|r|}{ Phenoloxidase } & \multicolumn{2}{|r|}{ Lysosomes } & \multicolumn{2}{|r|}{ Peroxidase } & \multicolumn{2}{|c|}{ Nonspecific Esterases } & GST \\
\hline $\begin{array}{l}\text { Morus alba var. } \\
\text { Rosa }\end{array}$ & & & $0.003 *$ & & $0.001 *$ & & $0.768 \mathrm{~ns}$ & 0.545 & & $0.052 *$ \\
\hline \multicolumn{2}{|c|}{ Morus alba var. Morittiana } & \multicolumn{2}{|r|}{$0.136 \mathrm{~ns}$} & \multicolumn{2}{|r|}{$0.882 \mathrm{~ns}$} & \multicolumn{2}{|r|}{$0.576 \mathrm{~ns}$} & \multicolumn{2}{|c|}{$0.040 \mathrm{~ns}$} & $0.051 *$ \\
\hline \multicolumn{2}{|c|}{ Morus alba var. Laevigata } & \multicolumn{2}{|r|}{$0.028 *$} & \multicolumn{2}{|r|}{0.0 ケ^* } & & $0.048 *$ & \multicolumn{2}{|c|}{$0.000 *$} & $0.004 *$ \\
\hline
\end{tabular}

* Means statistical significantly different $(\mathrm{P} \leq 0.05)$.

ns Means no significant differences between treatments 

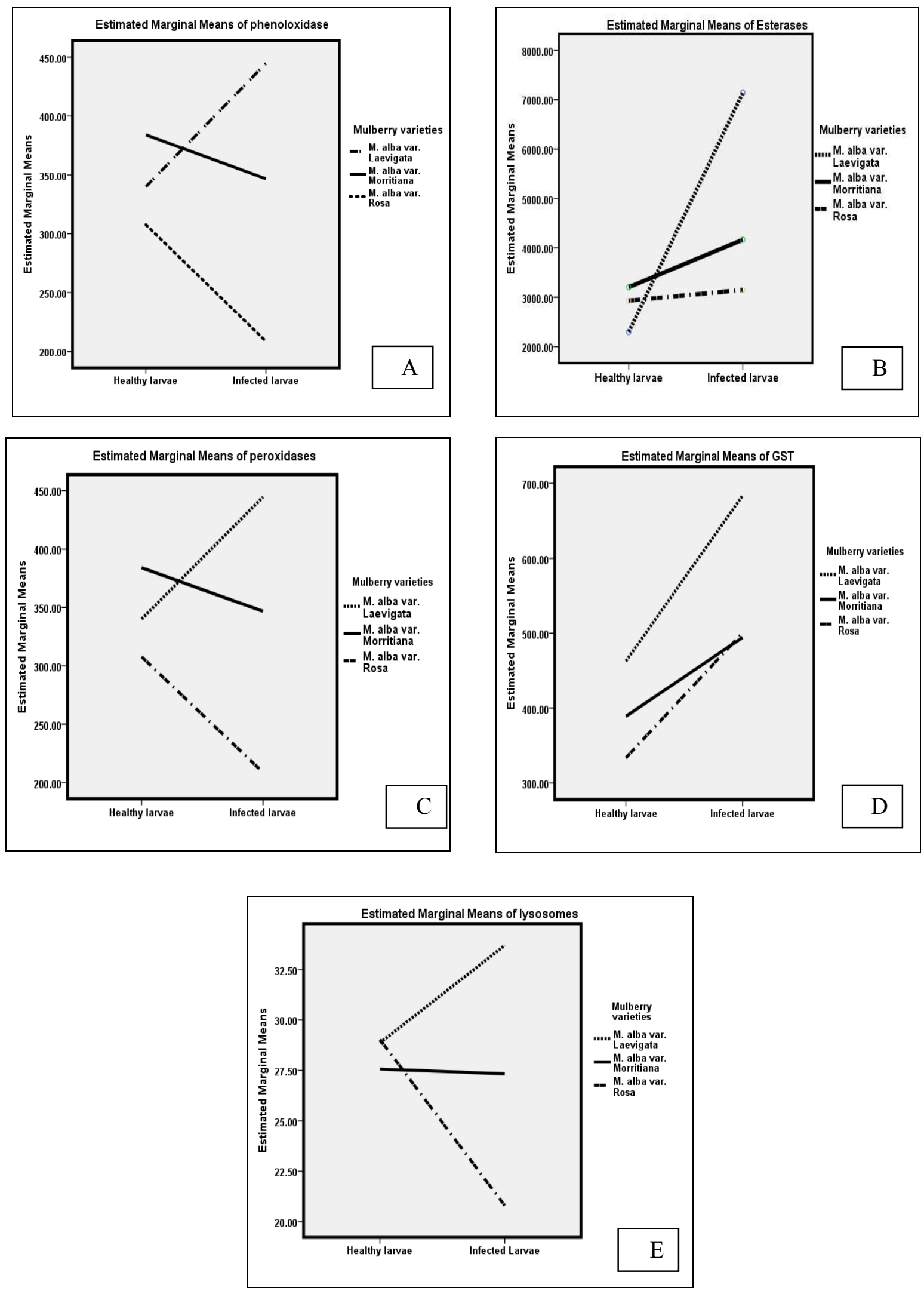

Figure (1): Mean of enzymes sp. activities of non-infected and infected Bombyx mori larvae fed on different varieties of mulberry leaves 
The interaction effects between mulberry varieties and bacterial contagious infection on the studied enzymes activity in Bombyx mori larval haemolymph:

Table (3) show the significant effects of infection on GST and Esterases sp. activity $(\mathrm{P}=0.000)$ while there were no significant effects of infection on other observed enzymes sp. activity, $(\mathrm{P}>0.05)$. Mulberry varieties have significant effects on all the observed enzymes sp. activity, $(\mathrm{P}<0.05)$. While interaction between infection and mulberry varieties show that the both factors significantly affect on Esterases, lysosomes and phenoloxidase sp. activity $(\mathrm{P}<0.05)$.

Table (3): The interaction effects between mulberry varieties and bacterial contagious infection on the studied enzymes activity in Bombyx mori larval haemolymph

\begin{tabular}{lccccc}
\hline Source & GST & Eesterases & Lysosomes & Peroxidases & Phenoloxidase \\
\hline Infection & $0.000 *$ & $0.000^{*}$ & $0.322 \mathrm{~ns}$ & $0.072 \mathrm{~ns}$ & $0.446 \mathrm{~ns}$ \\
Mulberry & $0.001^{*}$ & $0.000^{*}$ & $0.003 *$ & $0.000^{*}$ & $0.000^{*}$ \\
Infection * mulberry & $0.256 \mathrm{~ns}$ & $0.000^{*}$ & $0.002 *$ & $0.325 \mathrm{~ns}$ & $0.000^{*}$ \\
\hline
\end{tabular}

ns: Means no significant differences between treatments

* Means statistical significantly different $(\mathrm{P} \leq 0.05)$

\section{DISCUSSION}

Since the host plants are important biotic factors with strong influences on the ecology and evolution of herbivores, and their specialist natural enemies such as pathogens and endoparasitoids, so that specialist herbivores insects may respond very differently to host plant defensive chemical composition and nutritive value, Lampert (2012). These varied responses may be apparent as coupling with important physiological functions linked to survival. Results concluded from our study on the significant variations of enzymes activity in Bombyx mori larval haemolymph after feeding on different mulberry varieties, adding to our observations about the bacterial contagious infection on these larvae, it is interesting to note that, host plant were shown to affect immunity of insects to natural bacterial contagious, susceptibility to the bacterial diseases and the expression of their immune defences. Similar results were found in many other insects (Emad et al., 2016; Shikano et al., 2010; Vogelweith et al., 2015).

Present data cleared that phenoloxidase, and lysosomes enzymes decreased in haemolymph of infected larvae fed on M. alba var. Rosa and M. alba var. Morittiana while they increased in infected larvae fed on M. alba var. Laevigata, which mean that larvae fed on $M$. alba var. Laevigata leaves may have more diseases tolerance or immunity because of the high level of phenoloxidase which lead to high tolerance response against pathogenic bacteria (Reddy and Venkatappa, 2016). The lysosomes was the main antibacterial factor responsible for immunity of vaccinated insects thus upon pathogens infection, antibacterial proteins, lysozymes rapidly appear in the haemolymph after infection with bacteria (Reddy et al., 2012)

Experiments with three lepidopteran larvae of Galleria mellonella, Bombyx mori and Agrius convolvuli, similarly, have showed increased lysozyme activity upon immune challenging by Escherichia coli (Yu et al., 2002).
Peroxidase activity values significantly different between mulberry varieties, larvae fed on M. alba var. Laevigata leaves had the highest significant peroxidases value. Infection significantly reduced peroxidase activity values in haemolymph of larvae fed on all mulberry varieties leaves. Same results stated by Vengateswari et al. (2020) who found that (POX) activity in Spodoptera litura increased in 2-4 hours as a result of Bacillus thuringiensis infection of all treated groups, after that, there was decreased in all groups.

Nonspecific esterases and GSP sp. activity were increased in haemolymph of larvae fed on the three tested mulberry varieties after infection. In non-infected larvae, nonspecific esterases were the highest value when larvae fed on M. alba var. Morittiana while GSPs were the highest value in larvae fed on $M$. alba var. Laevigata. Similar results, GST activity increasing after infection, obtained by Vengateswari et al. (2020)

Esterases, degradation enzymes, may eliminate toxic molecules generated during microbial infection of the silkworm, B. mori. Therefore higher esterase activity was induced by the stimulation of bacterial infection (Shiotsuki and Kato, 1999). The Glutathione-Stransferases (GSTs) are play a central role in detoxification of endogenous and xenobiotic compounds also are involved in physiological processes such as protection against oxidative stress (Enayati et al., 2005; Kostaropoulos et al., 1996).

Kasmaeiand Mahesha (2012) found that the esterases may be used as marker molecules during the evolution of new breeds of silkworm B. mori with better economic characters. On the contrary, obtained present data declared that although nonspecific esterases in larvae fed on $M$. alba var. Laevigata was the lowest value in the non-infected larvae, they increased to be the highest value after infection which mean it is better to evaluate esterases in larvae challenging diseases which done by Somasundaram et al. (2013). They focused on the investigations of induced proteins in the haemolymph of silkworm 
breeds challenged with pathogens and recommended to make them as biochemical markers for associating the immunity of the different silkworm races of the $B$. mori.

The interaction effects between mulberry varieties and infection on the different studied enzymes sp. activity indicated that mulberry varieties affect disease responses in larvae. Thus it is recommended to give an attention to host plant while evaluating infection response or breeding new tolerant or immune insect races or hybrids. This information could be very useful for incorporating biological control program with pathogens for insect pest and their host plant.

\section{REFERENCES}

Abou El-Ela, A. A., M. M. Kariman and Y. F. Abdelaleim (2016). Study of pathogenicity and antibiotic effect on bacterial strains associated with Bombyx mori L. Journal of Entomological Research, 40(4): 327-332.

Alipanah, M., Z. Abedian, A. Nasiri and F. Sarjamei (2020). Nutritional Effects of Three Mulberry Varieties on Silkworms in Torbat Heydarieh. Psyche: A Journal of Entomology, 1-4. https://doi.org/10.1155/2020/6483427

De Azambuja, P., E. S. Garcia, N. A. Ratcliffe and J. D. Warthen Jr (1991). Immune-depression in Rhodnius prolixus induced by the growth inhibitor, azadirachtin. Journal of Insect Physiology. 37(10): 771-777.

Emad, M. S., M. Aziz, O. M. El-Monairy, N. M. Elbarky and H. F. Khalek (2016). Humoral Immune Response And Midgut Histopatholical Changes In Grasshopper Schistocerca gregaria Fed On Four Different Plants and Infected with Bacillus thuringiensis. IOSR Journal of Pharmacy and Biological Sciences, 11(4): 2429.

Enayati, A. A., H. Ranson and J. Hemingway (2005). Insect glutathione transferases and insecticide resistance. Insect Molecular Biology, 14(1): 38.

Habig, W. H., M. J. Pabst and W. B. Jakoby (1974). Glutathione S-transferases the first enzymatic step in mercapturic acid formation. Journal of biological Chemistry, 249(22): 7130-7139.

Hema, M., P. Sudhakara Rao, A. Naseema Begum and B. Rakesh (2011). Susceptibility status of popular silkworm breeds of Bombyx mori L., to infectious flacherie virus. Indian Journal of Animal Research, 45(2): 109-114.

Hou, C. X., P. J. Sun, X. J. Guo, Y. P. Huang and M. W. Li (2013). Marker-assisted selection in breeding silkworm strains with high silk production and resistance to the densonucleosis virus. Genetics and Molecular Research, 12(4): 4171-4178.

Ishaaya, I. (1971). Observations on the phenoloxidase system in the armored scales Aonidiella aurantii and Chrysomphalus aonidum. Comparative Biochemistry and Physiology
Part B: Comparative Biochemistry, 39(4): 935943.

Joshi, R. P., I. A. Raja and A. P. Bagde (2013). A preliminary survey on incidence of seasonal diseases in commercial crops of silkworms in Akola and Washim districts of Maharashtra. Bioscience Biotechnology Research Communications, 6(2): 202-204.

Kasmaei, F. G. and H. B. Mahesha (2012). Studies on the esterase and its relationship with commercial characters of silkworm Bombyx mori L. Annals of Biological Research, 3(11): 5273-5292.

Kostaropoulos, I., A. E. Mantzari and A. I. Papadopoulos (1996). Alterations of some glutathione S-transferase characteristics during the development of Tenebrio molitor (Insecta: Coleoptera). Insect Biochemistry and Molecular Biology, 26(8-9): 963-969

Kumar, K. K. and S. S. Naik (2011). Development of polyvoltinex bivoltine hybrids of mulberry silkworm, Bombyx mori L. tolerant to BmNPV. International Journal of Zoological Research, 7(4): 300.

Lampert, E. (2012). Influences of plant traits on immune responses of specialist and generalist herbivores. Insects, 3(2): 573-592.

Lemaitre, B. and J. Hoffmann (2007). The host defense of Drosophila melanogaster. Annual Review of Immunology, 25: 697-743

Mahmoud, K. (2017). Impact of Nutritional Composition of Wild and Cultivated Mulberry Varieties on Productivity and some Biochemical Parameters of Silkworm Bombyx mori L. (Bombycidae: Lepidoptera). Journal of Applied Plant Protection, 6(1): 25-30.

Montaño, A. M., F. Tsujino, N. Takahata and Y. Satta (2011). Evolutionary origin of peptidoglycan recognition proteins in vertebrate innate immune system. BMC evolutionary biology, 11(1): 79 .

Reddy, A. H. and B. Venkatappa (2016). Effect of Staphylococcus aureus infection on biochemical and antioxidant activities of fifth instar silkworm larvae (Bombyx mori L.). Journal of Bacteriology and Parasitology, 7: 2155-9597.

Reddy, G. S., B. Venkatappa, P. Seshapani, D. J. Rayalu and P. B. Janardhan (2012). Role of prophenoloxidase (propo) in silkworm immunity-determination of phenol oxidase (po) activity. The International Journal of Plant, Animal and Environmental Sciences, 2(2): 177-88.

Rosales, C. (2017). Cellular and molecular mechanisms of insect immunity. Insect Physiology and Ecology. In Teach Publications. CCBY, 179212.

Shikano, I., J. D. Ericsson, J. S. Cory and J. H. Myers (2010). Indirect plant-mediated effects on insect immunity and disease resistance in a tritrophic system. Basic and Applied Ecology, 11(1): 15-22. 
Shiotsuki, T. and Y. Kato (1999). Induction of carboxyl esterase isozymes in Bombyx mori by E. coli infection. Insect biochemistry and molecular biology, 29(8): 731-736.

Somasundaram, P., K. A. Kumar and A. Manjula (2013). Key Biochemical markers in silkworms challenged with immuno elicitors and their association in genetic resistance for survival. Global Journal of Bioscience and Biotechnology, 2(3): 290-295.

Van Asperen, K. (1962). A study of house fly esterase by means of sensitive colourimetric method. Journal of Insect Physiology, 8: 401-416.

Vengateswari, G., M. Arunthirumeni and M. S. Shivakumar (2020). Effect of food plants on Spodoptera litura (Lepidoptera: Noctuidae) larvae immune and antioxidant properties in response to Bacillus thuringiensis infection. Toxicology reports, 7: 1428-1437.

Vetter, J. L., M. P. Steinberg and A. I. Nelson (1958). Enzyme assay, quantitative determination of peroxidase in sweet corn. Journal of agricultural and food chemistry, 6(1): 39-41.
Vogelweith, F., J. Moreau, D. Thiéry and Y. Moret (2015). Food-mediated modulation of immunity in a phytophagous insect: An effect of nutrition rather than parasitic contamination. Journal of insect physiology, 77: 55-61.

Yang, Y., H. Tang, Y. Zhang, F. Zhu, P. Lü, Q. Yao and K. Chen (2018). Research progress on the immune mechanism of the silkworm Bombyx mori. Physiological Entomology, 43(3): 159168.

Yu, K. H., K. N. Kim, J. H. Lee, H. S. Lee, S. H. Kim, K. Y. Cho, M. H. Nam and I. H. Lee (2002). Comparative study on characteristics of lysozymes from the hemolymph of three lepidopteran larvae, Galleria mellonella, Bombyx mori, Agrius convolvuli. Developmental and comparative immunology, 26(8): 707-713. https://doi.org/10.1016/s0145$305 x(02) 00027-7$.

Zafar, B., A. W. Shabir and M. A. Malik (2013). A review: Disease resistance in mulberry silkworm Bombyx mori L. Asian Journal of Science and Technology, 4: 157-166.

\section{الاختلافات في الاستجابة المناعية بين يرقات فراشة الحرير التوتية التي تتذذى على أصناف توث مختلفة فئة

